\title{
HIV, syphilis and hepatitis B coinfections in Mkushi, Zambia: a
}

\section{cross-sectional study [version 1; peer review: 2 approved with}

\section{reservations]}

\author{
Cibangu Katamba(D1), Theresa Chungu1 ${ }^{1}$ Chisali Lusale ${ }^{1,2}$ \\ ${ }^{1}$ ART Department, Mkushi District Hospital, Mkushi, Zambia \\ ${ }^{2}$ Administration Department, Mkushi District Hospital, Mkushi, Zambia
}

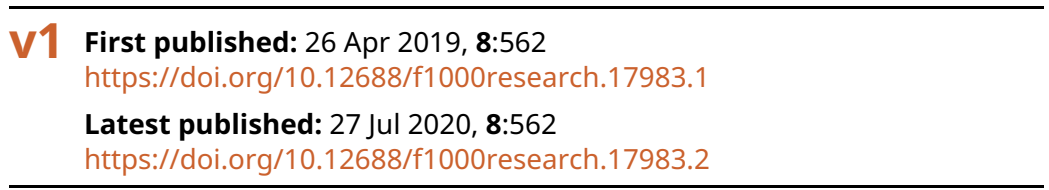

\section{Abstract}

Background: Human immunodeficiency virus, syphilis and hepatitis B virus (HBV) are major global public health problems. They are sexually transmitted diseases with overlapping modes of transmission and affected populations. The aim of this study is to assess the seroprevalence of HIV 1, hepatitis B virus and syphilis coinfections among newly diagnosed HIV individuals aged 16 to 65 years, initiating on antiretroviral therapy, in Mkushi, Zambia.

Methods: A total number of 126 sera were collected from HIV 1 infected patients attending Mkushi district hospital/ART clinic for antiretroviral therapy initiation. Hepatitis B surface antigen test and serologic test for syphilis were conducted between March and May 2018.

Results: Of the 126 participants, hepatitis B surface antigen (HBsAg) was detected with a prevalence of $9.5 \%$ among newly diagnosed HIV infected patients, while that of syphilis was as high as $40.5 \%$ in this same population group. Three patients recorded HIV coinfections with both syphilis and hepatitis B virus (2.4\%) at the same time. After analysis, the results indicate that there was no significant association between gender for both dependent variables: HIV/syphilis or HIV/hepatitis B virus coinfections (alpha significance level >0.05). Those who had a history of syphilis infection in the past were more likely than those who had none to be HIV-syphilis coinfected (53.6\% vs $34 \%$, respectively; odd ratio [OR] 2.236; 95\% confidence interval [CI] 1.045 - 4.782).

Conclusion: The high prevalence rates for HIV, HBV, and syphilis coinfections strongly indicate the need for HBV and syphilis screening for HIV infected individuals. Furthermore, the high number of patients previously treated for syphilis who retest positive for syphilis in this study calls for use of the Venereal Disease Research Laboratory test to identify true syphilis infection (titers $\geq 1: 8$ dilutions, strongly suggestive).

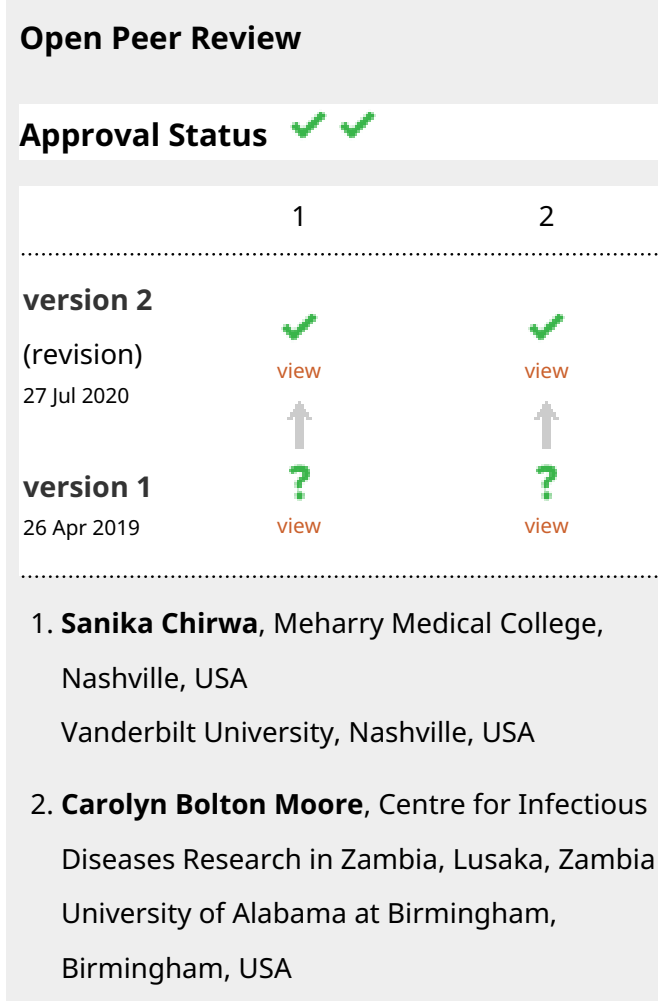

Any reports and responses or comments on the article can be found at the end of the article. 


\section{Keywords}

HIV, Hepatitis B, Syphilis, Coinfections

\section{Corresponding author: Cibangu Katamba (patrickkatamba@gmail.com)}

Author roles: Katamba C: Conceptualization, Data Curation, Formal Analysis, Investigation, Methodology, Project Administration, Resources, Software, Supervision, Validation, Writing - Original Draft Preparation; Chungu T: Conceptualization, Formal Analysis, Investigation, Project Administration, Validation, Visualization, Writing - Original Draft Preparation; Lusale C: Conceptualization, Data Curation, Methodology, Supervision, Validation, Visualization, Writing - Review \& Editing

Competing interests: No competing interests were disclosed.

Grant information: The author(s) declared that no grants were involved in supporting this work.

Copyright: $\odot 2019$ Katamba C et al. This is an open access article distributed under the terms of the Creative Commons Attribution License, which permits unrestricted use, distribution, and reproduction in any medium, provided the original work is properly cited.

How to cite this article: Katamba C, Chungu T and Lusale C. HIV, syphilis and hepatitis B coinfections in Mkushi, Zambia: a crosssectional study [version 1; peer review: 2 approved with reservations] F1000Research 2019, 8:562

https://doi.org/10.12688/f1000research.17983.1

First published: 26 Apr 2019, 8:562 https://doi.org/10.12688/f1000research.17983.1 


\section{Introduction}

Hepatitis B virus, together with syphilis and human immunodeficiency virus (HIV), are important public health challenges worldwide $^{1}$, they are transmitted through sex (Sexual transmitted diseases, STDs) $)^{2-5}$ and cross over affected populations ${ }^{1}$. The World Health Organization (WHO) reported an estimated 36.9 million people were living with HIV in $2016^{6,7}$. It was also reported that 248 million had chronic Hepatitis B virus (HBV) infection (persistent $\mathrm{HBs} \mathrm{Ag} \geq$ six months) ${ }^{8}$.

It is estimated that about a million sexually transmitted diseases are acquired daily throughout the world ${ }^{5}$. Moreover, STDs have impact on neonatal, sexual and reproductive health. They can also cause severe complications if not treated. Additionally, STDs pose major a socioeconomic challenge in the form of treatment costs ${ }^{5,9,10}$. Many studies have demonstrated a two-sided relationship between HIV and a number of STDs, including syphilis and $\mathrm{HBV}^{4}$. Syphilis and $\mathrm{HBV}$ has the potential to increase genital and plasma HIV 1 RNA levels. This increase can increase the likelihood of transmission of HIV 1 to others. In the same way, HIV 1 infection to impact the clinical manifestation, the therapeutic outcome and the HBV/syphilis disease progression ${ }^{4}$.

HIV is associated with a higher prevalence of both HBV and Hepatitis C Virus (HCV) in Sub-Saharan Africa ${ }^{11-13}$ in this region, many people living with HIV are HBV or HCV coinfected. About $8 \%$ of individuals infected with HIV were HBV coinfected in another study conducted in this region ${ }^{14}$. In a trial conducted in Sub-Saharan Africa ${ }^{15}$, a number of factors were associated with high rates of HIV and syphilis coinfection, including: young age, divorce, widowhood, or separation. Although it is helpful to recognize syphilis risk factors, many women without the risk factor characteristics were syphilis-seroreactive ${ }^{15}$. Also, a high proportion of prevalent rapid plasminogen reagin (RPR)-positive infections remain serofast despite treatment ${ }^{16}$.

In a number of studies conducted in Zambia ${ }^{17-29}$, it has been observed that HIV and chronic hepatitis B (CHB) coinfection was common in both children and adults. It was also observed in these patients that many risk factors such as liver complications and impaired immunologic recovery increased morbidity and mortality. In these settings, syphilis infection remains prevalent in HIV infected adults ${ }^{30}$. As HIV, syphilis and HBV coinfections are clinically consequential, there is great need to screen for syphilis and HBV in people living with HIV/AIDS. The aim of this study was to determine the prevalence of HIV1, HBV and Treponema pallidum serological markers, and therefore their coinfection prevalence among newly diagnosed HIV individuals attending ART clinic in Mkushi rural district of Zambia.

\section{Methods}

\section{Ethical considerations}

This study was approved by Mkushi District Health Office. Participants were informed and provided verbal consent prior to enrollment in the study. Samples were collected as part of routine recommended national baseline tests before initiating ART, therefore only verbal consent was sought.

\section{Study design}

We performed a cross-sectional study to assess the seroprevalence of HIV 1, HBV and syphilis coinfections among newly diagnosed HIV individuals aged 16 to 65 years, initiating on cART, in Mkushi, Zambia. Sociodemographic and clinical data were collected from study subjects including age, sex, number of years of education, marital status, residence, occupation, household income, HIV transmission route, history of tuberculosis, past syphilis infection, and WHO clinical staging. A data collection sheet (Extended data ${ }^{31}$ ) was used to collect information in addition to client' files.

Inclusion and exclusion criteria: this study included a patient population starting ART between March and May 2018, aged 16 to 65 years old, confirmed HIV 1 infection, being ART naïve (never taken ART for their HIV infection), regardless of WHO clinical staging. Subjects previously exposed to ART, children below the age of 16 , and clients with HIV 2 or HIV 1 \& 2 coinfections were excluded. A total number of 126 subjects were included.

Diagnosis: All tests were performed at Mkushi hospital laboratory. Four milliliters of venous blood were collected from each client using aseptic technic. Following centrifugation, sera were separated and tested immediately for HIV antibodies. HIV serologic test was conducted using Determine screening test (ALERE) (CHASE BUFFER REF 7D2243, ALERE Medical Co. Ltd. Japan); followed by SD Bioline confirmatory test, discriminating between HIV 1 \& HIV 2. (SD HIV1/2 3.0) (Assay diluent Lot 03ADDC013, SD Standard diagnostics, Inc. Hepatitis B virus infection was assessed by an immunochromatographic test (one step rapid test, Lot No. HBPDR00117, NeckLife, Punjab), following the manufacturer's instructions. Syphilis serology was examined using rapid plasma reagin (RPR) (one Step Rapid Test, Lot No. SYS-02-18Q, Ensure Biotech, Hyderabad-500 076), following the manufacturer's instructions.

Statistical analysis: The collected data were analyzed using the IBM SPSS statistics software (trial version 20). The Chi-Square test was used for analysis of the differences between proportions and $\mathrm{p}<0.05$ was considered as significant. The statistical analysis of frequencies was also conducted and the confidence interval was set at $95 \%$.

\section{Results}

Of the 126 participants, 46 were male $(36.5 \%)$ and 80 were female $(63.5 \%), 102$ were between the age of 19 and 40 years excluded $(81 \%), 100$ had primary education $(79.4 \%)$. While 66 patients were married $(52.4 \%)$, the rest were either divorced (30/126), never married (22/126) or widowed (8/126).

A total number of 126 blood samples were collected from HIV 1 infected patients attending Mkushi district hospital/ART clinic for antiretroviral therapy initiation (see underlying data ${ }^{24}$ ). HIV 1, HBV, and Syphilis coinfections were recorded together in $2.4 \%$ of cases $(3 / 126)$. 
Table 1 shows the prevalence of syphilis coinfection with HIV by age group.

The overall syphilis seroprevalence was $40.5 \%$ (51/126) in the studied population. HIV infected patients in the age group 20 - 29 years recorded the highest syphilis prevalence $47 \%$ (24/51), followed by the age group $30-39$ years at $29 \%$ (15/51), while those in the age group below 20 years recorded the lowest prevalence of $2 \%(1 / 51)$.

The below table shows the hepatitis B virus and syphilis coinfections results by gender among HIV infected subjects (Table 2).

Hepatitis B surface antigen (HBsAg) was detected with a prevalence of $9.5 \%$ (12/126) among newly diagnosed HIV infected patients, while that of syphilis was as high as $40.5 \%(51 / 126)$ in this same population group. The above data was analyzed and the results indicate that there was no significant association between gender and syphilis (Chi square value $=0.373$, $\mathrm{p}=0.542$ ). This study also shows that HBV presence was independent of gender (alpha significance level $>0.05$ ).

A past medical history was taken from each individual to obtain information on past syphilis infection. The results of past and current syphilis are shown in the table below (Table 3).

Finally, those HIV clients who had a history of syphilis infection in the past were more likely than those who had none to be

Table 1. Positive syphilis serostatus by age group.

\begin{tabular}{l|l|c|c|c|c|c|}
\hline \multicolumn{7}{|c|}{ Current syphilis by age group crosstabulation } \\
\hline Count & \multicolumn{5}{c|}{ Age group } & Total \\
\hline & & $<\mathbf{2 0}$ & $\begin{array}{c}\mathbf{2 0}-\mathbf{2 9} \\
\text { years }\end{array}$ & $\begin{array}{c}\mathbf{3 0 - 3 9} \\
\text { years }\end{array}$ & $\begin{array}{c}\mathbf{4 0} \text { and } \\
\text { above }\end{array}$ \\
\hline $\begin{array}{l}\text { Current } \\
\text { Syphilis }\end{array}$ & Positive & 1 & 24 & 15 & 11 & 51 \\
\hline Total & Negative & 3 & 36 & 27 & 9 & 75 \\
\hline & & 4 & 60 & 42 & 20 & 126 \\
\hline
\end{tabular}

Table 2. HIV, HBV and syphilis coinfections.

\begin{tabular}{|l|l|l|l|l|}
\hline \multicolumn{5}{|c|}{ Hepatitis B Virus } \\
\hline & Male & Female & Total \\
\hline Reactive & 4 & 8 & 12 \\
\hline Non-reactive & 42 & 72 & 114 \\
\hline \multicolumn{3}{|r|}{ Current Syphilis } \\
\hline Reactive & 17 & 34 & 51 \\
\hline Non-reactive & 29 & 46 & 75 \\
\hline
\end{tabular}

Table 3. Past vs current syphilis risk estimate.

\begin{tabular}{|c|c|c|c|c|}
\hline \multicolumn{5}{|c|}{ Past syphilis by current syphilis crosstabulation } \\
\hline \multicolumn{5}{|l|}{ Count } \\
\hline & & \multicolumn{2}{|c|}{ Current Syphilis } & \multirow{2}{*}{ Total } \\
\hline & & Positive & Negative & \\
\hline \multirow{2}{*}{ Past Syphilis } & Positive & 22 & 19 & 41 \\
\hline & Negative & 29 & 56 & 85 \\
\hline \multicolumn{2}{|l|}{ Total } & 51 & 75 & 126 \\
\hline
\end{tabular}

HIV-syphilis coinfected (53.6\% vs 34\%, respectively; OR 2.236; $95 \%$ CI 1.045 - 4.782). The relative Odds of HIV-Syphilis coinfection is calculated at 1.573 (95\% CI: $1.044-2.370)$.

\section{Discussion and conclusion}

The correlates of HIV, syphilis and hepatitis B coinfections were age (between 20 and 39 years), primary education, and of course sexual activity. This may be influenced by the rural settings where our study was conducted (especially low level of education). The HBV/HIV coinfections prevalence of $9.5 \%$ in this study is in line with the prevalence of $9.9 \%$ documented in Zambia by Kapembwa and colleagues ${ }^{27}$, and also the 12.2 reported by Vinikoor et al. ${ }^{19}$. The later also demonstrated that HIV coinfected adult males were more likely to be coinfected with HBV than their female counterparts. This contrast to our findings may be due to our small sample size. In our study, Pearson Chi-square analysis showed no statistically significant difference between gender for both HIV/HBV and HIV/Syphilis coinfections. Our findings demonstrate that HIV infected clients are more likely to be infected with other STIs, especially syphilis. The coinfection prevalence of $40.5 \%$ for HIV and syphilis agrees with previous study conducted in Zambia (43\%) by Odom and colleagues ${ }^{16}$. We found past syphilis infection to have positive association with two-fold increase risk of HIV/syphilis coinfections.

CONCLUSION: The high prevalence rates for HIV, HBV, and syphilis coinfections strongly indicate the need for $\mathrm{HBV}$ and syphilis screening for HIV infected individuals. The 2018 Zambian consolidated guidelines for prevention and treatment of HIV infection to address the management of these coinfections $^{32}$. However, there is urgent need to monitor the implementation of HBV and syphilis testing among HIV infected subject to close the gap between policy and practice. Furthermore, in previous study conducted in Zambia, Odom and colleagues $^{16}$ demonstrated that a high proportion of RPR positive infections remain serofast despite treatment. The high number of patients previously treated for syphilis who retest positive for syphilis in this study calls for use of the Venereal Disease Research Laboratory test to identify true syphilis infection (titers $\geq 1: 8$ dilutions, strongly suggestive) ${ }^{33}$. Both government and Non-governmental organizations need to up their efforts to support these health care service needs appropriately. 
Data availability

Underlying data

Harvard Dataverse: Replication Data for: HIV, SYPHILIS AND HEPATITIS B COINFECTIONS IN MKUSHI RURAL, ZAMBIA: a cross-sectional study. https://doi.org/10.7910/DVN/AK3JZR ${ }^{34}$

This project contains the following underlying data:

- $\quad$ HIV_HBV_SYPHILIS.tab (Seroprevalence data)

\section{Extended data}

Harvard Dataverse: Cibangu, Katamba, 2019, "Replication Data for: HIV, SYPHILIS AND HEPATITIS B COINFECTIONS IN MKUSHI RURAL, ZAMBIA: a cross-sectional study". https://doi. org/10.7910/DVN/6SNMQS ${ }^{31}$
This project contains the following extended data:

Data collection sheet.docx (data collection sheet)

Grant information

The author(s) declared that no grants were involved in supporting this work.

\section{Acknowledgments}

We thank the management of Mkushi district hospital, the ART staff, and the laboratory personnel for their cooperation in facilitating this investigation.
1. Easterbrook PJ, Roberts T, Sands A, et al:: Diagnosis of viral hepatitis. Curr Opin HIV AIDS. 2017; 12(3): 302-314.

PubMed Abstract | Publisher Full Text | Free Full Text

2. Mutagoma M, Nyirazinyoye L, Sebuhoro D, et al.: Syphilis and HIV prevalence and associated factors to their co-infection, hepatitis $B$ and hepatitis $C$ viruses prevalence among female sex workers in Rwanda. BMC Infect Dis. 2017; 17(1): 525 .

PubMed Abstract | Publisher Full Text | Free Full Text

3. Thio $\mathrm{CL}$ : Hepatitis $\mathrm{B}$ and human immunodeficiency virus coinfection. Hepatology. 2009; 49(5 Suppl): S138-45.

PubMed Abstract | Publisher Full Text

4. Chun HM, Carpenter RJ, Macalino GE, et al.: The Role of Sexually Transmitted Infections in HIV-1 Progression: A Comprehensive Review of the Literature. J Sex Transm Dis. 2013; 2013: 176459, 15.

PubMed Abstract | Publisher Full Text | Free Full Text

5. Carmona-Gutierrez D, Kainz K, Madeo F: Sexually transmitted infections: old foes on the rise. Microb Cell. 2016; 3(9): 361-362. PubMed Abstract | Publisher Full Text | Free Full Text

6. World Health Organization: Global health sector response to HIV 2000-2015 focus on innovations in Africa: progress report. Geneva: World Health Organization; 2016

Reference Source

7. Stover J, Andreev K, Slaymaker E, et al: Updates to the spectrum model to estimate key HIV indicators for adults and children. AIDS. 2014; 28 Suppl 4 S427-S434.

PubMed Abstract | Publisher Full Text | Free Full Text

8. Schweitzer A, Horn J, Mikolajczyk RT, et al: Estimations of worldwide prevalence of chronic hepatitis B virus infection: a systematic review of data published between 1965 and 2013. Lancet. 2015; 386(10003): 1546-1555. PubMed Abstract | Publisher Full Text

9. World Health Organization: Draft global health sector strategies: Sexually transmitted infections, 2016-2021. 2015. Reference Source

10. World Health Organization: Sexually Transmitted Infections (STIs). 2015. Reference Source

11. Barth RE, Huijgen Q, Taljaard J, et al.: Hepatitis B/C and HIV in sub-Saharan Africa: an association between highly prevalent infectious diseases. A systematic review and meta-analysis. Int J Infect Dis. 2010; 14(12): e1024-e1031. PubMed Abstract | Publisher Full Text

12. Moges F, Kebede Y, Kassu A: Seroprevalence of HIV, Hepatitis B infections and syphilis among street dwellers in Gondar city, Northwest Ethiopia. Ethiop $J$ Health Dev. 2006; 20(3)

Publisher Full Text

13. Shimelis $\mathrm{T}$, Tassachew $\mathrm{Y}$, Tadewos $\mathrm{A}$, et al:: Coinfections with hepatitis $\mathrm{B}$ and $\mathrm{C}$ virus and syphilis among HIV-infected clients in Southern Ethiopia: a crosssectional study. HIV AIDS (Auckl). 2017; 9: 203-210. PubMed Abstract | Publisher Full Text | Free Full Text

14. Coffie PA, Egger M, Vinikoor MJ, et al.: Trends in hepatitis B virus testing practices and management in HIV clinics across sub-Saharan Africa. BMC Infect Dis. 2017; 17(Suppl 1): 706.

PubMed Abstract | Publisher Full Text | Free Full Text

15. Potter D, Goldenberg RL, Read JS, et al.: Correlates of Syphilis Seroreactivity
Among Pregnant Women: The HIVNET 024 Trial in Malawi, Tanzania, and Zambia. NIH Public Access. Sex Transm Dis. 2006; 33(10): 604-609. PubMed Abstract | Publisher Full Text | Free Full Text

16. Dionne-Odom J, Karita E, Kilembe W, et al.: Syphilis treatment response among HIV-discordant couples in Zambia and Rwanda. Clin Infect Dis. Oxford University Press on behalf of the Infectious Diseases Society of America. 2013; 56(12): 1829-37.

PubMed Abstract | Publisher Full Text | Free Full Text

17. Peebles K, Nchimba L, Chilengi R, et al.: Pediatric HIV-HBV Coinfection in Lusaka, Zambia: Prevalence and Short-Term Treatment Outcomes. J Trop Pediatr. 2015; 61(6): 464-467.

PubMed Abstract | Publisher Full Text | Free Full Text

18. Vinikoor MJ, Sinkala E, Mweemba A, et al:: Elevated AST-to-platelet ratio index is associated with increased all-cause mortality among HIV-infected adults in Zambia. HHS Public Access. Liver Int. 2015; 35(7): 1886-1892. PubMed Abstract | Publisher Full Text | Free Full Text

19. Vinikoor MJ, Musukuma K, Munamunungu V, et al.: Implementation of routine screening for chronic hepatitis B virus co-infection by HIV clinics in Lusaka, Zambia. HHS Public Access. J Viral Hepat. 2015; 22(10): 858-860. PubMed Abstract | Publisher Full Text | Free Full Text

20. Yager P, Domingo GJ, Gerdes J: Point-of-care diagnostics for global health. Annu Rev Biomed Eng. 2008; 10: 107-44.

PubMed Abstract | Publisher Full Text

21. Vinikoor MJ, Mulenga L, Siyunda A, et al.: Association between hepatitis B coinfection and elevated liver stiffness among HIV-infected adults in Lusaka, Zambia. HHS Public Access. Trop Med Int Health. 2016; 21(11): 1435-1441. PubMed Abstract | Publisher Full Text | Free Full Text

22. Pang T, Peeling RW: Diagnostic tests for infectious diseases in the developing world: two sides of the coin. Trans R Soc Trop Med Hyg. 2007; 101(9): 856-7. PubMed Abstract | Publisher Full Text

23. Chisenga CC, Musukuma K, Chilengi R, et al:: Field performance of the Determine HBsAg point-of-care test for diagnosis of hepatitis B virus coinfection among HIV patients in Zambia. HHS Public Access. J Clin Virol. 2018 98: 5-7.

PubMed Abstract | Publisher Full Text | Free Full Text

24. Hoffmann CJ, Charalambous S, Thio CL, et al:: Hepatotoxicity in an African antiretroviral therapy cohort: the effect of tuberculosis and hepatitis B. AIDS 2007; 21(10): 1301-8.

PubMed Abstract | Publisher Full Text

25. Wandeler G, Musukuma K, Zürcher S, et al.: Hepatitis B Infection, Viral Load and Resistance in HIV-Infected Patients in Mozambique and Zambia. PLoS One. 2016; 11(3): e0152043.

PubMed Abstract | Publisher Full Text | Free Full Text

26. Wandeler G, Gsponer T, Bihl F, et al.: Hepatitis B virus infection is associated with impaired immunological recovery during antiretroviral therapy in the Swiss HIV cohort study. J Infect Dis. 2013; 208(9): 1454-8. PubMed Abstract | Publisher Full Text

27. Kapembwa KC, Goldman JD, Lakhi S, et al:: HIV, Hepatitis B, and Hepatitis C in Zambia. J Glob Infect Dis. 2011; 3(3): 269-274. PubMed Abstract | Publisher Full Text | Free Full Text

28. Hawkins C, Christian B, Ye J, et al.: Prevalence of hepatitis B co-infection and response to antiretroviral therapy among HIV-infected patients in Tanzania. 
AIDS. 2013; 27(6): 919-27. PubMed Abstract | Publisher Full Text

29. Kasolo F, Sakala I, Baboo K: Paris, France: Conference on HIV Pathogenesis and Treatment; Hepatitis B virus infection in human immunodeficiency virus seropositive patients at the University Teaching Hospital, Lusaka, Zambia: Interrelationship. [Abstract no. 963]. 2nd. 2003.

30. Makasa M, Fylkesnes K, Michelo $\mathrm{C}$, et al:: Declining syphilis trends in concurrence with HIV declines among pregnant women in Zambia: observations over 14 years of national surveillance. Sex Transm Dis. 2012, 39(3): 173-81.

PubMed Abstract | Publisher Full Text

31. Katamba C: Replication Data for: HIV, SYPHILIS AND HEPATITIS B COINFECTIONS IN MKUSHI RURAL, ZAMBIA: a cross-sectional study. Harvard
Dataverse, V1. 2019.

http://www.doi.org/10.7910/DVN/6SNMQS

32. Zambia Consolidated Guidelines for prevention and treatment of HIV infection Republic of Zambia, Ministry of Health. 2018.

Reference Source

33. World Health Organization: Sexually transmitted and other reproductive tract infections: a guide to essential practice. Geneva: World Health Organization; 2005.

Reference Source

34. Katamba C: Replication Data for: HIV, SYPHILIS AND HEPATITIS B COINFECTIONS IN MKUSHI RURAL, ZAMBIA: a cross-sectional study. Harvard Dataverse, V1. 2019.

http://www.doi.org/10.7910/DVN/AK3JZR 


\title{
Open Peer Review
}

\section{Current Peer Review Status: ? ?}

\section{Version 1}

Reviewer Report 23 June 2020

https://doi.org/10.5256/f1000research.19668.r64070

(C) 2020 Bolton Moore C. This is an open access peer review report distributed under the terms of the Creative Commons Attribution License, which permits unrestricted use, distribution, and reproduction in any medium, provided the original work is properly cited.

\author{
Carolyn Bolton Moore \\ ${ }^{1}$ Centre for Infectious Diseases Research in Zambia, Lusaka, Zambia \\ 2 University of Alabama at Birmingham, Birmingham, AL, USA
}

Thank you for the opportunity to review this manuscript. Overall the manuscript is sound but there are several grammatical errors and some sentences that do not make sense eg the reference to the National Guidelines. Additionally, there does not seem to be ethical approval. My understanding is that Mkushi District Health Office is the administrative body that falls under the Ministry of Health and manages the public health services in that area. Unless they have a special mandate, of which I am not aware, they are not authorized to provide Ethical Clearance as they are not considered a regulatory body. They are, however, required to give permission for research to occur in their facilities. Given that this study involves human subjects, I recommend getting retrospective ethics approval if not yet obtained or, if it has been obtained, including this in the manuscript from a recognised regulatory authority. Also, please include the total number of patients who were seen during the same period as the enrolment (ie the denominator), it is not clear what proportion of patients who were seen, enrolled in the study and had a specimen drawn. Please also check citations- the paragraph that starts with ... in Zambia (17-29) includes references that are regional but not necessarily in Zambia. Lastly, I suggest using STI instead of STD as it appears many of these infections were subclinical.

Is the work clearly and accurately presented and does it cite the current literature? Partly

Is the study design appropriate and is the work technically sound? Yes

Are sufficient details of methods and analysis provided to allow replication by others? Yes

If applicable, is the statistical analysis and its interpretation appropriate? Yes 
Are all the source data underlying the results available to ensure full reproducibility? Partly

\section{Are the conclusions drawn adequately supported by the results?}

Yes

Competing Interests: No competing interests were disclosed.

Reviewer Expertise: Infectious Disease in Zambia. Paediatric HIV. Epidemiology.

I confirm that I have read this submission and believe that I have an appropriate level of expertise to confirm that it is of an acceptable scientific standard, however I have significant reservations, as outlined above.

Author Response 06 Jul 2020

Cibangu Katamba, Mkushi Hospital, Mkushi, Zambia

Thank you very much for reviewing this manuscript.

The grammatical errors have been revised and the new version will be availed soon.

Waiver for ethical clearance was sought and obtained from the ERES Converge Zambian Institutional Review Board (IRB), the authority to publish was sought and obtained from the Zambian National Health Research Authority (NHRA). This will also appear in the new version.

The total number of patients who were seen during this period has also been included as the enrollment. Citations have been checked and corrected accordingly. The term STI has been used instead of STD.

Competing Interests: None

Reviewer Report 03 February 2020

https://doi.org/10.5256/f1000research.19668.r58393

(C) 2020 Chirwa S. This is an open access peer review report distributed under the terms of the Creative Commons Attribution License, which permits unrestricted use, distribution, and reproduction in any medium, provided the original work is properly cited.

\section{Sanika Chirwa}

${ }^{1}$ Department of Neuroscience \& Pharmacology, Meharry Medical College, Nashville, TN, USA

2 Adjunct, Department of Pharmacology, Vanderbilt University, Nashville, TN, USA

There is great potential in the presented study in terms of highlighting HIV + HBV + syphilis comorbid profile within rural settings in Zambia. This information could guide the distribution of pertinent resources needed to curtail the infections while identifying gaps in the drive to end the HIV epidemic. However, the manuscript is not written to best advantage and will require 
significant revisions to be impactful. Within this context, the authors may wish to consider the following concerns.

\section{INTRODUCTION}

This has accurate information but fails to specifically indicate relevance and need for study. What are the current prevalence estimates for HIV/HBV and/or syphilis co-infections in Mkushi? in Zambia? Is this information lacking and, therefore, partly formed the basis for the research study?

Are laboratory-based screening and/or diagnostic tests for the three infections routinely conducted together in much of Zambia, or this is lacking and provided another impetus for the study?

METHODS

- Clarify if the "Mkushi District Health Office" has formal authority to independently review and give ethical approval to conduct clinical research studies consistent with the norm.

- Indicate how study participants were informed of study, and how (and who) conducted the enrollment into the study.

State what percentage of new HIV cases initiated on CART did the reported 126 patients (i.e., enrolled in study between March and May 2018) reflect.

- It is unclear how many 4-mL venous blood draws were carried out on each patient. Were these blood draws separate from routine blood draws for patient care at the hospital?

Provide more information on how the screening/diagnostics tests performed actually work. Indicate their limitations and/or likelihood of false-positives. For example, Rapid Plasma Reagin for syphilis detects nonspecific antibodies produced by the body while fighting other RESULTS infections like Lyme disease. How was this checked in study?

Presented data are scanty and lack details. The authors are encouraged to expand this section and give additional information as well as correct errors in counts.

Consider reporting socioeconomic and demographic characteristics of participants in Table format. Give values as mean \pm STD here and elsewhere, accordingly.

Stated syphilis seroprevalence is 51 of 126 cases. This is then subdivided into age groups, i.e., 1 for below 20 years; 24 for 20-29 years; and 15 for 30 - 39 years. But this yields a total of 40 and not 51 cases. What happened to the missing 11 patients?

Like with syphilis, should also report "seroprevalence" data for HIV and HBV both by age and gender. Authors need to be consistent accordingly.

Need clarification on the reliability of the collection of "past syphilis infection" history. How exactly was this done?

More rigorous statistical analyses needed to properly interpret data and show significance as applicable. The significance of findings are unconvincing (and lost) as reported.

DISCUSSION 
Interpretation and significance of findings are unconvincing. It is difficult to make an independent assessment since presented data lack much detail.

Need to explain what gaps in knowledge have been filled by the study. For example, how will this information assist with patient care and/or re-direction of resources for concomitant screenings/diagnosis of HIV, HBV, and syphilis?

Are the above services readily available in all health centers in Zambia, or there is a disparity between urban and rural health centers? Explain.

Need to discuss the limitations of the research study.

Is the work clearly and accurately presented and does it cite the current literature? Partly

Is the study design appropriate and is the work technically sound?

Partly

Are sufficient details of methods and analysis provided to allow replication by others? No

If applicable, is the statistical analysis and its interpretation appropriate? Partly

Are all the source data underlying the results available to ensure full reproducibility? Partly

Are the conclusions drawn adequately supported by the results? Partly

Competing Interests: No competing interests were disclosed.

Reviewer Expertise: Neuroscience \& Clinical Pharmacologist - actively engaged in both basic and clinical research. Later includes focus on patient-centered care of HIV continuum of care with a focus on pediatric HIV.

I confirm that I have read this submission and believe that I have an appropriate level of expertise to confirm that it is of an acceptable scientific standard, however I have significant reservations, as outlined above.

Author Response 06 Jul 2020

Cibangu Katamba, Mkushi Hospital, Mkushi, Zambia

Thank you very much for reviewing this manuscript.

The relevance and need for the study have been included. The number of participants informed of the study and how/ who conducted the study have been described. The $4 \mathrm{MI}$ 
venous blood draws were the routine blood draws for ART clients base line tests as recommended by the national guidelines. Limitation of screening diagnostic tests have been described. Data errors have been corrected. The total number of patients who were seen during this period has also been included as the enrollment. Citations have been checked and corrected accordingly.

The waiver for ethical clearance was sought and obtained from the ERES Converge Zambian Institutional Review Board (IRB), the authority to publish was sought and obtained from the Zambian National Health Research Authority (NHRA). This will also appear in the new version. The limitations of the research have also been discussed.

Competing Interests: None

The benefits of publishing with F1000Research:

- Your article is published within days, with no editorial bias

- You can publish traditional articles, null/negative results, case reports, data notes and more

- The peer review process is transparent and collaborative

- Your article is indexed in PubMed after passing peer review

- Dedicated customer support at every stage

For pre-submission enquiries, contact research@f1000.com 